\title{
QUALITY ENHANCING OF CAKE USING WHITE WATERMELON RINDS
}

\author{
MAHMOUD, AMAL H. ${ }^{1}$, ZAHRAT EL-OLA M. MOHAMED ${ }^{2}$ \\ NADRA S. Y. HASSAN ${ }^{3}$ AND EBTEHAL A. EL-KHOLANY ${ }^{1}$
}

1. Department of Special food and nutrition., Food Technology Research Institute, ARC, Giza, Egypt

2. Department of Crops Technology Research, Food Technology Research Institute, ARC, Giza, Egypt.

3. Experimental Kitchen Research Unit, Food Technology Research Institute, $A R C$, Giza, Egypt

(Manuscript received 26 April 2017)

\begin{abstract}
$\mathrm{F}$ ruit and vegetable wastes and their by-products are formed in great amounts during industrial processing which presents a serious problem to environment. So they need to be managed or prepared to be utilized. The aim of the present investigation is to study the possibility of white watermelon rind powder (WMRP) utilization in manufacturing cake by partial substitution of wheat flour at different levels $(10,20,30$ and $40 \%$ ). The effect of white watermelon rind powder substitution on the physicochemical, sensory properties and shelf life of the cakes was investigated. Results showed that fiber content of the produced cakes was increased by increasing the substitution levels of WMRP. Minerals content particularly $\mathrm{Ca}, \mathrm{K}$ and $\mathrm{Mg}$, content was increased in WMRP cake samples. Substitution with WMRP significantly improved the cake volume. Results of textural analysis showed that watermelon rind powder decreased all textural parameters. Regarding to color character, cakes became darker as the level of substitution increased. The sensory evaluation results showed that cakes prepared with WMRP had high mean scores for overall acceptability except in case of $40 \%$ substitution level. All WMRP cake samples exhibited a lower microbiological count than control at zero time and during storage periods. So, the substitution with WMRP in cakes processing led to prolong the shelf life of cake compared with control sample with respect to microbiological assay.

Keywords: Watermelon rinds, Cake, Substitutions, Physicochemical properties, Sensory evaluation
\end{abstract}

\section{INTRODUCTION}

The utilization of wastes of fruit and vegetable processing as a source of functional ingredients is a promising field in food industry is a great challenge to minimize wastes arising from processing operations and released to the environment. (Schieber et al., 2001).

Watermelon is an important vegetable crop in Egypt, which can be exported to other countries. Increased cultivation of watermelon in the recent period is due to higher income and limited period of their stay in the ground. It has been widely 
cultivated especially in Northern Regions of Egypt, such as Kafr El-Sheikh Governorate and newly reclaimed lands. (Ministry of Agriculture, 2012).

Watermelon is grown in the warmer regions of the world. Half of a watermelon fruit is edible while the other half (the rind) goes to waste. Watermelon rind is one of the major solid wastes generated by several restaurants, cottage fruit juice producers and food industries. Unfortunately, more than $90 \%$ of the rind is discarded indiscriminately into the environment thereby constituting environmental challenges. This waste rind is not presently being utilized for any value added process due to limited research activities focusing on the possible conversion of the waste to other valuable products (Souad et al., 2012).

Watermelon rinds are edible and contain many hidden nutrients, but most people avoid eating them due to their unappealing flavor. They are sometimes used as a vegetable. Pickled watermelon rind is commonly consumed in the Southern US (Rattray and Diana, 2012). Water melon rind can be converted into value added product by drying and can be used for the preparation of bakery products with the supplementation of rind powder in a very easily (Al-Sayed and Ahmed, 2013).

Bakery products constitute one of the most consumed foods in the world. Among them, cakes are popular and are associated in the consumer's mind with a delicious sponge product with desired organoleptic characteristics. Bakery products are generally used as a source for incorporation of different nutritionally rich ingredients for their diversification (Sudha et al., 2007).

In the recent years, an upward trend in bakery products with increased nutritional value, such as fiber-enriched products, has been observed. In order to increase the fiber content in cakes and muffins, several raw materials such as bran and outer layers of legume (Kaack and Pedersen, 2005 and Sudha et al., 2007) have been used. The quality of cake depends on the quantity and quality of ingredient especially the flour used in preparation. It was found that mixing two or more of different materials will help to solve the deficiency problem of cereal as low nutritional value (Patel and Rao, 1995).

Therefore, the aim of this research paper is to study the effect of incorporation of white watermelon rind in cakes on formulas physicochemical properties and sensory characteristics as well as shelf life. 


\section{MATERIALS AND METHODS}

\section{Materials}

Watermelon Fruit used in this investigation was obtained from local market in Cairo, Egypt. Wheat flour (72\% extraction rate) was obtained from South Cairo Company of milling. Sugar, baking powder, corn oil, salt, eggs, skimmed milk and vanilla were purchased from the local market. All chemicals were of the analytical reagent grade.

\section{Methods}

\section{Preparation of watermelon rind powders}

The white watermelon rind was separated from the washed fresh watermelon fruits and cut into small pieces by a sharp knife and dried with oven dryer at $50 \pm 5^{\circ} \mathrm{C}$ then the dehydrated pieces were ground in a laboratory mill (JKA-Labora technic, Janke and Kunkel Type: MFC, Germany) to pass through 80 mesh sieve, then packaged and stored in a refrigerator $\left(4^{\circ} \mathrm{C}\right)$ until used.

\section{Cake preparation}

Cake samples were prepared according to the modified method of Bennion and Bamford (1983). The recipe of cake formula is summarized in Table (1) expressing the different ratios of white watermelon rind powders used in this study. Cake was prepared by mixing the sugar with oil and was creamed for 3 min at speed 5 in a kitchen aid mixture. The whole eggs were added and mixed in at the same speed for 2 min. The flour, baking powder and skimmed milk were added and the batter was mixed for $4 \mathrm{~min}$ at speed 2 . Cake batters were placed in each pan and baked in an oven at $180^{\circ} \mathrm{C}$ for $30 \mathrm{~min}$. After baking, cakes were removed from pans and cooled to room temperature, then packaged in polyethylene bags and stored at room temperature for 21 days. Samples were taken after removing from pans within $1 \mathrm{~h}$ and often 1 week intervals for analysis.

Table 1. Cakes formula prepared with white watermelon rind powder at different levels of substitutions.

\begin{tabular}{|c|c|c|c|c|c|c|c|c|}
\hline Ingredients & $\begin{array}{c}\text { Wheat } \\
\text { flour } \\
(\mathrm{g})\end{array}$ & $\begin{array}{c}\text { Sugar } \\
(\mathrm{g})\end{array}$ & $\begin{array}{c}\text { WMRP } \\
(\mathrm{g})\end{array}$ & $\begin{array}{c}\text { Corn } \\
\text { oil } \\
(\mathrm{g})\end{array}$ & $\begin{array}{c}\text { Eggs } \\
(\mathrm{g})\end{array}$ & $\begin{array}{c}\text { Skimmed } \\
\text { Milk } \\
(\mathrm{g})\end{array}$ & $\begin{array}{c}\text { Baking } \\
\text { Powder } \\
(\mathrm{g})\end{array}$ & $\begin{array}{c}\text { Vanilla } \\
(\mathrm{g})\end{array}$ \\
\hline Control & 100 & 85 & ----- & 65 & 85 & 3.0 & 3.8 & 0.6 \\
\hline W10 & 90 & 85 & 10 & 65 & 85 & 3.0 & 3.8 & 0.6 \\
\hline W20 & 80 & 85 & 20 & 65 & 85 & 3.0 & 3.8 & 0.6 \\
\hline W30 & 70 & 85 & 30 & 65 & 85 & 3.0 & 3.8 & 0.6 \\
\hline W40 & 60 & 85 & 40 & 65 & 85 & 3.0 & 3.8 & 0.6 \\
\hline
\end{tabular}

Water was added as needed 


\section{Analytical Methods}

The proximate chemical composition, ie. moisture, crude protein, ether extract, fiber and ash of raw materials and cake samples were determined according to AOAC (2007). Total carbohydrates were calculated by difference.

Water Absorption capacity (WAC) of white watermelon rind powder (WMRP) and wheat flour (72\% extraction) was determined according to AACC (2000)

Determination of Macro and Micro Elements for white watermelon rind Powder and Substituted cakes

Two grams of sample was weighed and heated in muffle furnace at $550^{\circ} \mathrm{C}$. Then the ashes were dissolved with $100 \mathrm{ml} 1 \mathrm{~N} \mathrm{HCl}$. Dissolved ash was analyzed for sodium, potassium, magnesium, calcium, iron and zinc content by using methods of AOAC (2007). Perkin Elmer (Model 3300, USA) atomic absorption spectrophotometer was used to determine these minerals.

\section{Physical Measurements of Cake}

Cake weight ( $\mathrm{g}$ ) was recorded after cooling for $1 \mathrm{~h}$. Cake volume $\left(\mathrm{cm}^{3}\right)$ was determined by rapeseed displacement method as described by AACC (2000).

Specific volume $\left(\mathrm{cm}^{3} \mathrm{~g}^{-1}\right)$ of cake was calculated by dividing volume by weight. Density $\left(\mathrm{g} \mathrm{cm}^{-3}\right)$ was calculated by dividing weight by volume.

\section{Texture Profile Analysis (TPA) of Cake}

Cake texture was determined by universal testing machine (Conetech, B type, Taiwan) provided with software according to Bourne (2003). An aluminum (25 mm diameter) cylindrical probe was used in a TPA double compression test to penetrate to $50 \%$ depth, at $1 \mathrm{mms}^{-1}$ speed test. Firmness (N), gumminess (N) chewiness (N), cohesiveness and springiness were calculated from TPA graphic.

\section{Determination of color of cake samples}

The color of cake samples was measured according to the method outlined by McGurie (1992). Color of cake (crust and crumb) was measured by using a hand-held tristimulus reflectance Colorimeter (Minolta Chroma Meter model CR-400, Konica Minolta, Japan). The apparatus provided $L$ (lightness with $L=100$ for lightness, and $L$ $=$ zero for darkness), a [(chromaticity on green $(-)$ to red $(+)], \mathrm{b}[$ (chromaticity on a blue $(-)$ to yellow $(+)]$.

\section{Sensory Evaluation of Cake}

Cake samples were organoleptically evaluated for its sensory characteristics. Slice of each cake sample was served to well train ten panelists on white, odorless and disposable plates. Samples were scored for shape, crust color, crust character, crumb color, brightness, crumb texture, softness, taste, odor and total score is the sum of all 
the tested characters. The evaluation was carried out according to Bennion and Bamford (1983).

\section{Water activity $\left(\mathrm{a}_{\mathrm{w}}\right)$}

Water activity $\left(\mathrm{a}_{\mathrm{w}}\right)$ of cake samples was measured with a Rotronic Hygro Lab EA10SCS (Switzerland) $a_{w}$ meter. The measurements were performed in triplicate.

\section{Microbiology}

The microbiological quality of stored cake for 3 weeks at an ambient temperature was evaluated by determining total fungal count ( $1 \mathrm{~g}$ sample) using malt yeast agar media to be as a good tool to estimate the shelf life according to Mislivec et al., (1992) and aerobic plate count using total count media (Swanson et al., 1992).

\section{Statistical Analysis}

For the analytical data, Mean values and \pm standard deviation are reported. The obtained data were subjected to one-way analysis of variance (ANOVA) at $P<0.05$. While Pearson correlation coefficient $(r)$ was used to compare the relationship between water absorption capacity and crude fiber of WMRP. (Steel and Torrie 1997).

\section{RESULTS AND DISCUSSION}

\section{Proximate composition and WAC}

The chemical composition and water absorption capacity (WAC) of white watermelon rind powder (WMRP) and wheat flour was determined and the results are given in Table (2).

Table 2. Chemical composition (\% on dry weight basis) and water absorption capacity (WAC) of white watermelon rind powder and wheat flour ( $72 \%$ extraction)

\begin{tabular}{|c|l|l|l|l|l|l|}
\hline Samples & \multicolumn{1}{|c|}{ Protein } & Crude Fiber & \multicolumn{1}{|c|}{ Ash } & \multicolumn{1}{c|}{ Fat } & \multicolumn{1}{c|}{$\begin{array}{c}\text { Total } \\
\text { carbohydrate }\end{array}$} & $\begin{array}{c}\text { WAC } \\
\left(\mathrm{gH}_{2} \mathrm{Og}^{-1}\right)\end{array}$ \\
\hline $\begin{array}{c}\text { White } \\
\text { watermelo } \\
\text { n powder }\end{array}$ & $\begin{array}{l}9.60^{\mathrm{b}} \\
\pm 0.14\end{array}$ & $\begin{array}{l}13.70^{\mathrm{a}} \\
\pm 0.03\end{array}$ & $\begin{array}{l}9.25^{\mathrm{a}} \\
\pm 0.21\end{array}$ & $\begin{array}{l}2.15^{\mathrm{a}} \\
\pm 0.028\end{array}$ & $\begin{array}{l}65.30^{\mathrm{b}} \pm \\
0.02\end{array}$ & $\begin{array}{l}7.57^{\mathrm{a}} \\
\pm 0.57\end{array}$ \\
\hline $\begin{array}{c}\text { Wheat } \\
\text { flour }\end{array}$ & $\begin{array}{l}10.85 \\
{ }^{\mathrm{a}} \pm 0.07\end{array}$ & $0.64^{\mathrm{b}} \pm 0.03$ & $\begin{array}{l}0.51^{\mathrm{b}} \pm \\
0.01\end{array}$ & $\begin{array}{l}0.94^{\mathrm{b}} \pm \\
0.02\end{array}$ & $\begin{array}{l}87.06^{\mathrm{a}} \pm \\
0.05\end{array}$ & $\begin{array}{l}1.78^{\mathrm{b}} \\
\pm 0.42\end{array}$ \\
\hline
\end{tabular}

Values are means of three replicates $\pm S D$.

Values, within the same column, followed by the same latter are not significant by different at 0.05 level.

Data in Table (2) showed that increase in protein and total carbohydrate content were significantly higher in wheat flour (72\% extract) compared with white watermelon powder. On the other hand, ash and fat content were higher in WMRP than in wheat flour.

Results in the same table showed that water absorption capacity (WAC) of white melon rind flour was significantly higher relative to wheat flour, this may be due the higher content of fiber in white melon rind flour. Sharma et al., (2013) reported that 
the high WAC of WMRP due to the greater number of hydroxyl groups existing in the fiber structures which allows more water interactions through hydrogen bonding. In addition, a positive correlation was found between fiber content and WAC of the white watermelon powder ( $r=0.99)$. Similar results were found by Al-Sayed and Ahmed (2013) who reported that watermelon rinds had high water absorption capacity (WAC) reached $7.7 \mathrm{gH}_{2} \mathrm{Og}^{-1}$.

Table 3. Proximate analysis of cake containing substituted flour with different levels of watermelon rind powder ( $\%$ on dry weight basis).

\begin{tabular}{|c|c|c|c|c|c|}
\hline Samples & Protein & Fiber & Ash & Fat & \multicolumn{1}{c|}{$\begin{array}{c}\text { Total } \\
\text { Carbohydrate }\end{array}$} \\
\hline $\begin{array}{c}\text { Control } \\
\text { Wheat } \\
\text { flour }\end{array}$ & $11.35^{\mathrm{a}} \pm 0.08$ & $0.71^{\mathrm{e}} \pm 0.02$ & $0.58^{\mathrm{e}} \pm 0.01$ & $19.46^{\mathrm{a}} \pm 0.27$ & $67.90^{\mathrm{a}} \pm 0.19$ \\
\hline W10 & $11.22^{\mathrm{a}} \pm 0.03$ & $1.29^{\mathrm{d}} \pm 0.035$ & $0.96^{\mathrm{d}} \pm 0.028$ & $19.53^{\mathrm{a}} \pm 0.41$ & $67.00^{\mathrm{b}} \pm 0.40$ \\
\hline W20 & $10.89^{\mathrm{b}} \pm 0.09$ & $2.69^{\mathrm{c}} \pm 0.077$ & $1.44^{\mathrm{c}} \pm 0.02$ & $19.79^{\mathrm{a}} \pm 0.23$ & $65.19^{\mathrm{c}} \pm 0.22$ \\
\hline W30 & $10.74^{\mathrm{bc}} \pm 0.056$ & $3.49^{\mathrm{b}} \pm 0.06$ & $1.86^{\mathrm{b}} \pm 0.02$ & $20.07^{\mathrm{a}} \pm 0.27$ & $63.85^{\mathrm{d}} \pm 0.33$ \\
\hline W40 & $10.62^{\mathrm{c}} \pm 0.04$ & $4.89^{\mathrm{a}} \pm 0.04$ & $2.51^{\mathrm{a}} \pm 0.07$ & $20.26^{\mathrm{a}} \pm 0.33$ & $61.72^{\mathrm{e}} \pm 0.43$ \\
\hline
\end{tabular}

W10, W20, W30 and W40: cake prepared with $10,20,30$ and $40 \mathrm{~g}$ of white water melon rind powder/100 g of wheat flour, respectively. Values are means of three replicates \pm SD values, in the same column, followed by the same letters, are not significantly different at 0.05 level.

Data in Table (3) showed the chemical composition of the produced cakes. From the tabulated data, it could be observed that there were not significant differences in protein content between control cake sample and cake prepared with 10 $\%$ of watermelon rind powder. On the other hand, significant decreases among all treatments were detectable with raising the replacement level. Furthermore, utilization of white watermelon rind powder in cakes resulted in a significant increase in its fiber and ash content with increasing the level of substitution. Fiber content increased from 0.71 to $4.89 \%$ and ash increased from 0.58 to $2.51 \%$ respectively. The increment in ash and carbohydrate content were due to their higher content in the used substituted materials than in flour as shown in Table (3). These results agreed with Al-Sayed and Ahmed (2013) who found that the utilization of watermelon rind and sharlyn melon peel powder increase their bakery products contents of fiber. Fat content of cake samples was not significantly affected by substitution the wheat flour with white watermelon rind powder. Total carbohydrates of substituted cakes were significantly decreased as the substitution levels increased compared with control cake. 


\section{Minerals Content of white watermelon rind powder and Substituted Cake}

White watermelon rind powder and produced cake samples were analyzed for, calcium, iron, potassium, magnesium and zinc as presented in Table (4).

Table 4. Minerals Content of watermelon rind powder and the prepared cakes (mg $100 \mathrm{~g}^{-1}$ on dry weight basis)

\begin{tabular}{|l|c|c|c|c|c|}
\hline \multicolumn{1}{|c|}{ Samples } & Mg & $\mathrm{K}$ & $\mathrm{Ca}$ & $\mathrm{Fe}$ & $\mathrm{Zn}$ \\
\hline Water melon rind & 142.57 & 179.63 & 60.62 & 5.49 & 2.57 \\
\hline Control & 45.91 & 289.27 & 26.21 & 2.23 & 0.75 \\
\hline W10 & 53.94 & 346.37 & 29.32 & 2.46 & 1.04 \\
\hline W20 & 64.38 & 448.75 & 35.95 & 2.53 & 1.30 \\
\hline W30 & 79.99 & 578.00 & 42.02 & 2.75 & 1.44 \\
\hline W40 & 92.79 & 701.66 & 49.38 & 3.34 & 1.68 \\
\hline
\end{tabular}

W10, W20, W30 and W40: cake prepared with 10, 20, 30 and $40 \mathrm{~g}$ of white water melon rind powder/100 g of wheat flour, respectively.

Results showed that minerals content varied according to the WMRP substitution levels. Higher minerals content of WMRP cakes was observed compared to the control. The greatest increasing rate was observed in magnesium and $K$ of the substituted cake samples, particularly in $40 \%$ substitution levels. Concerning the micro mineral concentrations, the current data showed some increase in iron (Fe) and zinc $(\mathrm{Zn})$ values in the substituted cake. These results are due to that WMRP is a good source of these minerals.

El-Badry et al. (2014) reported that WMRP contained a higher amount of macroelements which is considered the most important of minerals such as calcium and magnesium as well as WMRP contained a considerable amount of both iron and zinc as important micro-elements.

Generally, WMRP is considered as a good source of macro and micro-elements and should be utilized in food fortification.

\section{Physical properties}

Physical properties (weight, volume, specific volume and density) of cakes, prepared by incorporating $10.0,20.0,30$ and $40.0 \%$ of white watermelon rind powder, are given in Table (5). Regarding weight data, it showed that there was no significant difference among the control cake and WMRP cakes except in case of $40 \%$ substitution level. Loaf volume and specific volume of cake samples containing white watermelon rind powder were significantly increased than that of control cake. The cake sample W20 (containing 20\% rind powder) gave the highest volume (146.5 \pm $2.12 \mathrm{~cm}^{3}$ and $\left.2.63 \pm 0.02 \mathrm{~cm}^{3} \mathrm{~g}^{-1}\right)$. This is due to presence of water absorbing matrix (oil, cellulose, hemicelluloses, lignin and other dietary fiber components) in rind powder which increased water holding capacity leading to enhancement of cake 
volume (Cauvain and Young, 2006). It was also observed that the specific volume of cake samples (in W10 to W40) were significantly increased with increasing the levels of rind powder in the formulation of cakes and thereafter decreased. Density of cake samples decreased compared with control. Substitution with $20 \%$ had the lowest density value $\left(0.38 \mathrm{gcm}^{-3}\right)$. These results are agreement with Al-Sayed and Ahmed, 2013). Hoque and Iqbal (2015) reported that $10.0 \%$ watermelon rind powder in cake formulations gave a higher cake volume value than those of 20.0 and $30.0 \%$ of rind powder samples.

Table 5. Physical properties of the produced cake prepared with different WMRP substitutions ratios.

\begin{tabular}{|c|c|c|c|c|}
\hline Samples & Weight $(\mathrm{g})$ & Volume $\left(\mathrm{cm}^{3}\right)$ & $\begin{array}{c}\text { Specific volume } \\
\left(\mathrm{cm}^{3} \mathrm{~g}^{-1}\right)\end{array}$ & $\begin{array}{c}\text { Density } \\
\left(\mathrm{gcm}^{-3}\right)\end{array}$ \\
\hline Control & $55.10^{\mathrm{b}} \pm 0.14$ & $135.0^{\mathrm{c}} \pm 1.41$ & $2.45^{\mathrm{b}} \pm 0.03$ & $0.41^{\mathrm{a}} \pm 0.01$ \\
\hline W10 & $55.29^{\mathrm{ab}} \pm 0.41$ & $140.0^{\mathrm{bc}} \pm 2.82$ & $2.45^{\mathrm{b}} \pm 0.03$ & $0.39^{\mathrm{a}} \pm 0.01$ \\
\hline W20 & $55.75^{\mathrm{ab}} \pm 0.35$ & $146.5^{\mathrm{a}} \pm 2.12$ & $2.63^{\mathrm{a}} \pm 0.02$ & $0.38^{\mathrm{b}} \pm 0.00$ \\
\hline W30 & $56.04^{\mathrm{ab}} \pm 0.65$ & $142.0^{\mathrm{ab}} \pm 2.82$ & $2.53^{\mathrm{b}} \pm 0.02$ & $0.39^{\mathrm{a}} \pm 0.00$ \\
\hline W40 & $56.04^{\mathrm{a}} \pm 0.65$ & $140.0^{\mathrm{bc}} \pm 1.41$ & $2.48^{\mathrm{b}} \pm 0.05$ & $0.40^{\mathrm{a}} \pm 0.01$ \\
\hline
\end{tabular}

W10, W20, W30 and W40: cake prepared with 10, 20, 30 and $40 \mathrm{~g}$ of white water melon rind powder/100 g of wheat flour, respectively. Values are means of three replicates $\pm S D$, Values, within the same column, followed by the same latter is not significant of different at 0.05 level.

\section{Texture analysis of Produced cake samples}

The texture parameters assessed from Texture Profile Analysis (TPA) curves are presented in Table (6). A significant decrease in firmness from (1.81 to $1.00 \mathrm{~N}$ ) was found in cake samples. Cohesiveness quantifies the internal resistance of food structure. It is the ability of a material to stick to itself. The TPA results showed that there was an increase in cohesiveness $(0.60$ to $0.71 \mathrm{~N})$ of cake samples with increasing the substitution level with water melon rind powder.

Gumminess is determined by hardness multiplied by cohesiveness. The TPA results showed a significant decrease in gumminess in cake samples from (1.09 to $0.71 \mathrm{~N}$ ) as well as significant decrease was observed in chewiness and springiness parameters in all cake samples in relative to control.

It could be concluded that according to the level of water melon rind powder, all TPA parameters decreased (except cohesiveness), corresponding with the fiber content in water melon rind powder in relative to wheat flour products. These results are in agreement with Gedrovica and Karklina (2009) who mentioned that as the amount of fiber was increased in the formation, the cake become softer. Naknaen et al. (2016) reported that the bakery product tended to become softer as the level of water melon rind powder increased. 
Table 6. Texture analysis of produced cake samples

\begin{tabular}{|l|l|l|l|l|l|}
\hline Samples & Firmness (N) & Cohesiveness & $\begin{array}{l}\text { Gumminess } \\
(\mathrm{N})\end{array}$ & Chewiness (N) & Springiness \\
\hline Control & $1.81^{\mathrm{a}} \pm 0.02$ & $0.60^{\mathrm{d}} \pm 0.00$ & $1.09^{\mathrm{a}} \pm 0.01$ & $0.78^{\mathrm{a}} \pm 0.01$ & $0.72^{\mathrm{a}} \pm 0.00$ \\
\hline W10 & $1.70^{\mathrm{b}} \pm 0.03$ & $0.63^{\mathrm{c}} \pm 0.00$ & $1.07^{\mathrm{a}} \pm 0.02$ & $0.74^{\mathrm{b}} \pm 0.01$ & $0.69^{\mathrm{b}} \pm 0.00$ \\
\hline W20 & $1.41^{\mathrm{c}} \pm 0.05$ & $0.66^{\mathrm{b}} \pm 0.01$ & $0.93^{\mathrm{b}} \pm 0.02$ & $0.63^{\mathrm{c}} \pm 0.00$ & $0.68^{\mathrm{c}} \pm 0.01$ \\
\hline W30 & $1.17^{\mathrm{d}} \pm 0.04$ & $0.70^{\mathrm{a}} \pm 0.02$ & $0.82^{\mathrm{c}} \pm 0.00$ & $0.49^{\mathrm{d}} \pm 0.00$ & $0.61^{\mathrm{d}} \pm 0.00$ \\
\hline W40 & $1.00^{\mathrm{e}} \pm 0.03$ & $0.71^{\mathrm{a}} \pm 0.00$ & $0.71^{\mathrm{d}} \pm 0.02$ & $0.39^{\mathrm{e}} \pm 0.02$ & $0.55^{\mathrm{e}} \pm 0.01$ \\
\hline
\end{tabular}

W10, W20, W30 and W40: cake prepared with 10, 20, 30 and $40 \mathrm{~g}$ of white water melon rind powder/100 g of wheat flour, respectively. Values are means of three replicates \pm SD. Values, within the same column, followed by the same latter is not significant of different at 0.05 level.

\section{Color values of cake samples}

Color measurement values $(L, a$, and $b)$ of the tested cake samples were show in Table (7).

Table 7. Color values of produced cakes samples.

\begin{tabular}{|l|c|c|c|c|c|c|}
\hline \multirow{2}{*}{ Samples } & \multicolumn{5}{|c|}{ Crumb } & \multicolumn{3}{c|}{ Crust } \\
\cline { 2 - 7 } & $\mathrm{L}$ & $\mathrm{a}$ & $\mathrm{b}$ & $\mathrm{L}$ & $\mathrm{a}$ & $\mathrm{b}$ \\
\hline Control & $72.61^{\mathrm{a}} \pm 0.04$ & $2.15^{\mathrm{d}} \pm 0.05$ & $28.98^{\mathrm{a}} \pm 0.16$ & $47.16^{\mathrm{a}} \pm 0.19$ & $13.36^{\mathrm{a}} \pm 0.134$ & $26.47^{\mathrm{e}} \pm 0.09$ \\
\hline W10 & $71.11^{\mathrm{b}} \pm 0.12$ & $2.30^{\mathrm{c}} \pm 0.05$ & $28.27^{\mathrm{b}} \pm 0.38$ & $47.02^{\mathrm{a}} \pm 0.16$ & $12.76^{\mathrm{b}} \pm 0.05$ & $27.16^{\mathrm{d}} \pm 0.09$ \\
\hline W20 & $69.97^{\mathrm{c}} \pm 0.19$ & $2.50^{\mathrm{b}} \pm 0.07$ & $27.30^{\mathrm{c}} \pm 0.04$ & $45.83^{\mathrm{b}} \pm 0.23$ & $12.48^{\mathrm{c}} \pm 0.08$ & $27.97^{\mathrm{c}} \pm 0.04$ \\
\hline W30 & $66.99^{\mathrm{d}} \pm 0.15$ & $2.62^{\mathrm{b}} \pm 0.03$ & $26.83^{\mathrm{c}} \pm 0.26$ & $43.44^{\mathrm{c}} \pm 0.14$ & $10.76^{\mathrm{d}} \pm 0.05$ & $29.03^{\mathrm{b}} \pm 0.09$ \\
\hline W40 & $61.52^{\mathrm{e}} \pm 0.39$ & $2.83^{\mathrm{a}} \pm 0.06$ & $25.95^{\mathrm{d}} \pm 0.06$ & $39.14^{\mathrm{d}} \pm 0.28$ & $10.05^{\mathrm{e}} \pm 0.09$ & $29.98^{\mathrm{a}} \pm 0.25$ \\
\hline
\end{tabular}

W10,W20,W30 and W40: cake prepared with 10, 20, 30 and $40 \mathrm{~g}$ of white water melon rind powder/100 g of wheat flour, respectively. * (lightness with $\mathrm{L}=100$ for lightness, and $\mathrm{L}=$ zero for darkness), a [(chromaticity on a green $(-)$ to red $(+)], \mathrm{b}[$ (chromaticity on a blue $(-)$ to yellow $(+)]$, Values are means of three replicates $\pm S D$. numbers in the same column, followed by the same letters, are not significantly different at 0.05 level.

Results indicate that crust and crumb color of cake samples varied with the quantity of the WMRP materials. The crust became darker as the watermelon rind powder levels increased compared with the control cake. Moreover, rind powder cake samples exhibited higher $b$ values than control.

Regarding to crumb color of cake samples, a value increased in watermelon rinds cake sample and the crumb color became darker. $L$ and $b$ values of the cake samples decreased with increase in the WMRP level. Therefore, the crumb of the control cake was lighter and more yellowish compared to the tested cakes. This result could be attributed to substituted materials and their interactions of tested cake. Majzoobi et al.(2012) reported that crumb color is affected by constituents in the cake formulation. 
The crumb color of the WMRP cake samples was generally more brownish than the control. (Hoque and Iqbal, 2015)

\section{Sensory evaluation of cake samples}

Sensory evaluation score of produced cake samples are illustrated in Table (8). The results showed that cake samples made from wheat flour substituted with 10 and $20 \%$ watermelon rind powder showed no significant difference in all their sensory properties in relative to control. The results showed that there are no significant differences between control and tested cake samples up to 20\% WMRP in shape and crust color parameters. There was no significant difference between control and tested cake samples up to $30 \%$ WMRP in Crust character, Brightness, Crumb texture and taste parameters. Morover, there was no significant change between 20 and 30\% substitution levels in all sensory prameters except in shape and crumb color. In addition, results showed a slight increased in odor character in tested cake (10 and 20\% WMRP). W40 Cake sample had the lowest scores in all sensory parameters compared to other cake samples. WMRP cake samples had a high total score except in case of $40 \%$ substitution level. It could be concluded that watermelon rind powder can be supplemented (up to 30\%) during preparation of cakes. Hoque and Iqbal ( 2015) mentioned that good quality watermelon rind powder cake may be processed incorporating $10.0 \%$ watermelon rind powder into the formulation of plain cake for improved nutritional value and other aspects.

Table 8. Sensory evaluation of the cake samples

\begin{tabular}{|c|c|c|c|c|c|c|c|c|c|c|}
\hline Samples & Shape & $\begin{array}{l}\text { Crust } \\
\text { color }\end{array}$ & $\begin{array}{l}\text { Crust } \\
\text { character }\end{array}$ & $\begin{array}{l}\text { Crumb } \\
\text { color }\end{array}$ & Brightness & $\begin{array}{l}\text { Crumb } \\
\text { texture }\end{array}$ & Softness & Taste & Odor & $\begin{array}{l}\text { Total } \\
\text { score }\end{array}$ \\
\hline Control & $\begin{array}{l}9.8^{\mathrm{a}} \pm \\
0.44\end{array}$ & $\begin{array}{l}9.8^{\mathrm{a}} \pm \\
0.44\end{array}$ & $\begin{array}{l}9.6^{\mathrm{a}} \pm \\
0.89\end{array}$ & $\begin{array}{l}9.6^{\mathrm{a}} \pm \\
0.89\end{array}$ & $\begin{array}{l}9.6^{\mathrm{a}} \pm \\
0.54\end{array}$ & $\begin{array}{l}9.8^{\mathrm{a}} \pm \\
0.45\end{array}$ & $\begin{array}{l}9.4^{\mathrm{a}} \pm \\
0.89\end{array}$ & $\begin{array}{l}14.65^{\mathrm{a}} \pm \\
0.65\end{array}$ & $\begin{array}{l}14.4^{\mathrm{a}} \\
\pm \\
0.89\end{array}$ & $\begin{array}{l}96.65^{\mathrm{a}} \pm \\
5.02\end{array}$ \\
\hline W10 & $\begin{array}{l}9.6^{\mathrm{a}} \pm \\
0.54\end{array}$ & $\begin{array}{l}9.4^{\mathrm{a}} \pm \\
0.54\end{array}$ & $\begin{array}{l}9.6^{\mathrm{a}} \pm \\
0.54\end{array}$ & $\begin{array}{l}9.4^{\mathrm{ab}} \\
\pm 0.54\end{array}$ & $\begin{array}{l}9.6^{\mathrm{a}} \pm \\
0.89\end{array}$ & $\begin{array}{l}9.4^{\mathrm{ab}} \\
\pm \\
0.54\end{array}$ & $\begin{array}{l}9.3^{\mathrm{a}} \pm \\
0.44\end{array}$ & $\begin{array}{l}14.5^{\mathrm{a}} \pm \\
0.35\end{array}$ & $\begin{array}{l}14.6^{\mathrm{a}} \\
\pm \\
0.22\end{array}$ & $\begin{array}{l}95.4^{\mathrm{a}} \pm \\
3.15\end{array}$ \\
\hline W20 & $\begin{array}{l}9.6^{\mathrm{a}} \pm \\
0.41\end{array}$ & $\begin{array}{l}9.05 \\
a^{\prime} \pm \\
0.27\end{array}$ & $\begin{array}{l}9.4^{\mathrm{a}} \pm \\
0.54\end{array}$ & $\begin{array}{l}9.1^{\mathrm{ab}} \\
\pm 0.74\end{array}$ & $\begin{array}{l}9.4^{\mathrm{a}} \pm \\
0.54\end{array}$ & $\begin{array}{l}9.4^{\mathrm{ab}} \\
\pm \\
0.55\end{array}$ & $\begin{array}{l}9.25^{\mathrm{a}} \pm \\
0.55\end{array}$ & $\begin{array}{l}14.4^{\mathrm{a}} \pm \\
0.54\end{array}$ & $\begin{array}{l}14.6^{\mathrm{a}} \\
\pm \\
0.41\end{array}$ & $\begin{array}{l}94.2^{\mathrm{ab}} \pm \\
3.84\end{array}$ \\
\hline W30 & $\begin{array}{l}8.9^{b} \pm \\
0.2^{2}\end{array}$ & $\begin{array}{l}8.3^{b} \pm \\
0.44\end{array}$ & $\begin{array}{l}9.0^{\mathrm{a}} \pm \\
0.40\end{array}$ & $\begin{array}{l}8.4^{\mathrm{bc}} \pm \\
0.54\end{array}$ & $\begin{array}{l}8.4^{a} \pm \\
0.54\end{array}$ & $\begin{array}{l}9.2^{\mathrm{ab}} \\
\pm \\
0.83\end{array}$ & $\begin{array}{l}9.1^{\mathrm{a}} \pm \\
0.55\end{array}$ & $\begin{array}{l}13.9^{\mathrm{a}} \pm \\
0.22\end{array}$ & $\begin{array}{l}14.4^{\mathrm{a}} \\
\pm \\
0.22\end{array}$ & $\begin{array}{l}89.6^{b} \pm \\
2.74\end{array}$ \\
\hline W40 & $\begin{array}{l}7.4^{c} \pm \\
0.41\end{array}$ & $\begin{array}{l}6.9^{c} \pm \\
1.14\end{array}$ & $\begin{array}{l}7.8^{b} \pm \\
1.09\end{array}$ & $\begin{array}{l}7.4^{c} \pm \\
1.14\end{array}$ & $\begin{array}{l}6.8^{b} \pm \\
1.64\end{array}$ & $\begin{array}{l}8.6^{b} \pm \\
0.89\end{array}$ & $\begin{array}{l}8.8^{\mathrm{a}} \pm \\
0.57\end{array}$ & $\begin{array}{l}12.0^{b} \pm \\
1.22\end{array}$ & $\begin{array}{l}14.1^{\mathrm{a}} \\
\pm \\
0.54\end{array}$ & $\begin{array}{l}79.8^{c} \pm \\
4.91\end{array}$ \\
\hline
\end{tabular}

W10,W20,W30 and W40: cake prepared with 10, 20, 30 and $40 \mathrm{~g}$ of white water melon rind powder/100 g of wheat flour, respectively. Data are presented as means $\pm \operatorname{SDM}(n=10)$ and numbers in the same column, followed by the same letters, are not significantly different at 0.05 level. 


\section{Water activity of produced cake samples.}

The $a_{w}$ is an important reference for the shelf life of foods, as it strongly influences the growth of micro-organisms. (Felisberto et al., 2015). Water activity plays an important role in the safety, quality, processing, shelf life, texture and sensory properties of confections. The water activity values of tested cakes are illustrated in Table (9).

The water activity of control cake at zero time had significantly higher value (0.895) than WMRP cake which prepared by substituting flour with 10,20 and $30 \%$ watermelon rind powder. These results are higher than data of Hanan and Abdelrahman (2013); who found that $a_{w}$ of control cake was 0.808 . Meanwhile, no significant difference in $\mathrm{a}_{w}$ between WMRP cake samples was found.

This result may due to higher water holding capacity and total fiber content of WMRP (Fernandez-Lopez et al., 2009). The value of water activity was increased up to 0.913 at the end of the storage time in the control sample. From Table (9), it could be noticed that water activity (aw) significantly decreased during storage period in all WMRP cake samples. The higher reduction of water activity was significantly observed in WMRP 30\% cake in sample relative to other WMRP cake samples. These results agreed with Hoque and Iqbal (2015).

Table 9. Water activity of cake samples

\begin{tabular}{|l|l|l|l|l|}
\hline Samples & Zero time & One weak & Two weak & Three weak \\
\hline control & $0.895^{\mathrm{Aa}} \pm 0.047$ & $0.898^{\mathrm{Aa}} \pm 0.025$ & $0.903^{\mathrm{Aa}} \pm 0.026$ & $0.913^{\mathrm{Aa}} \pm 0.035$ \\
\hline W 10 & $0.836^{\mathrm{Ba}} \pm 0.038$ & $0.763^{\mathrm{Bb}} \pm 0.037$ & $0.754^{\mathrm{Bb}} \pm 0.031$ & $0.732^{\mathrm{Bb}} \pm 0.024$ \\
\hline W 20 & $0.816^{\mathrm{Ba}} \pm 0.036$ & $0.735^{\mathrm{Cb}} \pm 0.042$ & $0.704^{\mathrm{Cb}} \pm 0.035$ & $0.684^{\mathrm{Cc}} \pm 0.019$ \\
\hline W 30 & $0.813^{\mathrm{Ba}} \pm 0.042$ & $0.725^{\mathrm{Cb}} \pm 0.039$ & $0.686^{\mathrm{Cc}} \pm 0.026$ & $0.563^{\mathrm{Dd}} \pm 0.022$ \\
\hline
\end{tabular}

W10,W20,W30 and W40: cake prepared with 10, 20,30 and $40 \mathrm{~g}$ of white water melon rind powder/100 g of wheat flour, respectively. Values are means of three replicates $\pm S D$, numbers separatly in the same column, and the same raw, followed by the same small letters are not significantly different at 0.05 level.

\section{Microbiology assays}

Table 10. Microbiological assays (CFU) of cake samples during storage periods at room temperatures $\left(25 \pm 5^{\circ} \mathrm{C}\right)$.

\begin{tabular}{|l|c|c|c|c|c|c|c|c|}
\hline \multirow{2}{*}{ Samples } & \multicolumn{4}{|c|}{ Total count } & \multicolumn{4}{|c|}{ Yeast \&mold } \\
\cline { 2 - 9 } & $\begin{array}{c}\text { Zero } \\
\text { time }\end{array}$ & $\begin{array}{c}\text { One } \\
\text { weak }\end{array}$ & $\begin{array}{c}\text { Two } \\
\text { weeks }\end{array}$ & $\begin{array}{c}\text { Three } \\
\text { weeks }\end{array}$ & $\begin{array}{c}\text { Zero } \\
\text { time }\end{array}$ & One weak & $\begin{array}{c}\text { Two } \\
\text { weeks }\end{array}$ & $\begin{array}{c}\text { Three } \\
\text { weeks }\end{array}$ \\
\hline control & $3 \times 10$ & $8 \times 10^{2}$ & $7 \times 10^{3}$ & $1.5 \times 10^{5}$ & NG & $1.0 \times 10^{1}$ & $52 \times 10^{3}$ & $6 \times 10^{4}$ \\
\hline W 10 & NG & $4 \times 10^{1}$ & $2.4 \times 10^{2}$ & $3.3 \times 10^{3}$ & NG & NG & $7 \times 10^{1}$ & $32 \times 10^{2}$ \\
\hline W 20 & NG & NG & $3 \times 10^{1}$ & $1.8 \times 10^{2}$ & NG & NG & NG & $12 \times 10^{2}$ \\
\hline W 30 & NG & NG & NG & $9 \times 10^{1}$ & NG & NG & NG & $2 \times 10^{1}$ \\
\hline
\end{tabular}

NG: No Growth 
Data in Table (10) showed the different microorganisms (bacteria, mould and yeast) present in cake prepared water melon rind powder with stored room temperature $\left(25 \pm 5^{\circ} \mathrm{C}\right)$ for 3 weaks.

Regarding microbiological quality criteria, the presence of microorganisms is the major factor affecting food safety and organoleptic properties. Cake is considered one of the most important bakery products for Egyptian people, either home-made or produced on commercial scale. The microbiological count is considered as a suitable monitor for shelf life of cake production. The microbial count for cake samples during storage time at room temperatures is displayed in Table (10). The results indicated that cake prepared by wheat flour substituted with WMRP had the lowest value of total bacterial count for all storage period than control cake. Total microbial count of WMRP cakes was decreased with increasing substitution levels. Moreover, $30 \%$ of WMRP substitution level showed no bacterial growth prolonged storage period (the bacterial count reached $\left.9 \times 10^{1} \mathrm{cfu} / \mathrm{g}\right)$.

Increasing of WMRP $(10,20$ and 30\%) caused a decrease in yeast and mold count during storage period. Moreover, the yeast and mold count in control sample was increased throughout the storage period. This result may due to reduction in water activity of WMRP cake samples during storage period. Water activity has a marked effect on the growth of microorganisms. Reduction of $a_{w}$ often affects microbial growth, the predominant microbial component and it increases shelf life as a result of the reduced availability of water for the microbial growth (Eskin and Robinson, 2001). Almost all microbial activity is inhibited below $a_{w}=0.6$, most fungi are inhibited below $a_{w}=0.7$, most yeasts are inhibited below $a_{w}=0.8$ and most bacteria below $a_{w}=0.9$ (Fellows, 2000).

\section{CONCLUSION}

According to physico-chemical properties and organoleptic evaluation of the processed cakes, it may be concluded that good quality watermelon rind powder cake could be processed by incorporation level up to $30 \%$. Utilization of white rind watermelon improved specific volume, density and texture profiles of produced cake. Cakes prepared with watermelon rind powder had high mean scores for over all acceptability except in case of $40 \%$ substitution level. This incorporation extends, also the shelf life of cakes.

\section{REFERENCES}

1. AACC. 2000. Approved Methods of the American Association of Cereal Chemists, $11^{\text {th }}$, , ed. AACC. St. Paul, MN. 
2. Al-Sayed, H.M.A. and Ahmed, A.R. 2013. Utilization of watermelon rinds and sharlyn melon peels as a natural source of dietary fiber and antioxidants in cake. Annals of Agricultural Science. 58(1): 83-95.

3. AOAC. 2007. Official Methods of Analysis of AOAC International. 18th Edition, AOAC, Washington D. C.

4. Bennion, E. B. and Bamford, G. S. 1983. The Technology of Cake Making. Leonard Hill Books, Great Britain by Builling and Son's Ed., London, 241p.

5. Bourne, M.C. 2003. Food Texture and Viscosity: Concept and Measurement. Elsevier Press, New York/London.

6. Cauvain, S. P. and Young, L.S. 2006. Baked Products: Science, Technology and Practice. Wiley-Blackwell, Oxford.

7. El-Badry, N., El-Waseif, M. A., Badr, S.A. and Ali, H. E. 2014. Effect of Addition Watermelon Rind Powder on the Rheological, Physiochemical and Sensory Quality Attributes of Pan Bread. Middle East Journal of Applied Sciences, 4(4): 1051-1046.

8. Eskin, M. and Robinson, D.S. 2001. Preface, in Food shelf life stability: chemical, biochemical, and microbiological changes, M. Eskin and D.S. Robinson, Editors., CRC Press, Boca Raton: USA. p. 3-35.

9. Felisberto, M. H. F., Wahanik, A. L., Gomes-Ruffi, C. R., Clerici, M. T. P. S., Chang, Y. K., and Steel, C. J. 2015. Use of chia (Salvia hispanica L.) mucilage gel to reduce fat in pound cakes. LWT-Food Science and Technology, 63(2): 1049-1055.

10. Fellows, P. 2000. Food Processing Technology. CRC Press Sahay, K. M. \& K. K. Singh. 2007. Unit Operations of Agricultural Processing (II revised) Vikas Publishing House Pvt. Ltd., New Delhi

11. Fernandez-Lopez, J., Sendra-Nadal, E., Navarro, C., Sayas, E., Viuda-Martos, M. and Pérez-Alvarez, J.A. 2009. Storage stability of a high dietary fiber powder from orange by-products. International Journal of Food Science and Technology , 44, 748-756.

12. Gedrovica, I. and Karklina, D. 2009. Characteristics of Cakes Enriched with Jerusalem artichoke Powder. Chemian Technology, 3, 50-55.

13. Hoque, M. and Iqbal, A.(2015). Drying of Watermelon Rind and Development of Cakes from Rind Powder International Journal of Novel Research in Life Sciences ,2 (1): 14-21.

14. Kaack, K. and Pedersen, L. 2005. Low energy chocolate cake with potato pulp and yellow pea hulls. European Food Research and Technology, 221: 367-375.

15. Majzoobi, M., Darabzadeh, N. and Farahnaky, A. 2012. Effects of percentage and particle size of wheat germ on some properties of batter and cake. J. Agric. Sci. Technol. 14, 827- 836. 
16. McGurie, R. G. 1992. Reporting of Objective Color Measurements. HortScience, 27: $1254-1255$.

17. Ministry of Agriculture. 2012. Agricultural statistics, Economic Issues sector, Cairo, Egypt: 78-115.

18. Mislivec, P. B, Beuchat, L. R. and Cousin, M. A. 1992. Yeast and molds. In: Compendium of Methods for the Microbiological Examination of Foods, 3rd ed. Vanderzant. C. and Splittstoesser, D. F. (eds.). pp. 239-249. American Public Health Associat4ion, Washington, DC.

19. Naknaen P., Itthisoponkul, T., Sondee A. and Angsombat.N. 2016. Utilization of Watermelon Rind Waste as a Potential Source of Dietary Fiber to Improve Health Promoting Properties and Reduce Glycemic Index for Cookie Making. Food Sci. Biotechnol., 25(2): 415-424.

20. Patel, M.M. and Rao, G.V. 1995. Effect of untreated, roasted and germinated black gram (Phaseolus mungo) flours on the physicochemical and biscuit (cookie) making characteristics of soft wheat flour. Journal of Cereal Science, 22: 285-291.

21. Rattray and Diana. 2012. Southern U.S. Cuisine: Judy's Pickled Watermelon Rind. Southernfood.about.com.

22. Schieber, A., F. C. Stintzing, and R. Carle. 2001. By-products of plant processing as a source of functional compounds-Recent developments. Trends in Food Science and Technology, 12(11):401-413.

23. Sharma, P, Velu, V, Indrani, D, Singh, RP. 2013. Effect of dried guduchi (Tinospora cordifolia) leaf powder on rheological, organoleptic and nutritional characteristics of cookies. Food Res. Int., 50: 704-709.

24. Souad, A.M., Jamal, P. and Olorunnisola, K. S. 2012. Effective jam preparations from watermelon waste International Food Research Journal, 19(4): 1545-1549.

25. Steel, R.G.D. and Torrie, J.H. 1997. Principles and Procedures of Statistics. A Biometrical approach. McGraw Hill Book Co., New York, USA.

26. Sudha, M. L., Vetrimani, R. and Leelavathi, K. 2007. Influence of Fibre from Different Cereals on the Rheological Characteristics of Wheat Flour Dough and on Biscuit Quality. Food Chemistry,. 100.4, 1365-1370.

27. Swanson, K. M. J., Busta, F. F., Peterson, E. H. and Johnson, M. G. 1992

28. Colony count methods. In: Compendium of Methods for the Microbiological Examination of Foods, 3rd ed. Vanderzant. C. and Splittstoesser, D. F (eds). PP. 75-95. American Public Health Association, Washington, D. C. 


\title{
تحسين خواص جودة الكيك باستخدام قثور البطيخ
}

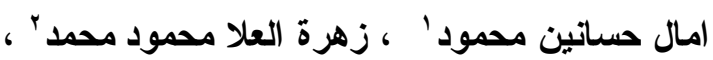

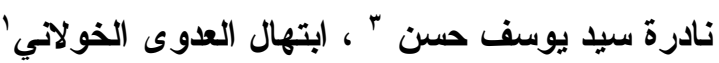

\begin{abstract}
ا ـ قسم بحوث الاغذية الخاصة ، معهر بحوث نكنولوجيا الاغنية ، مركز البحوث الزراعية ، الجيزة- مصر

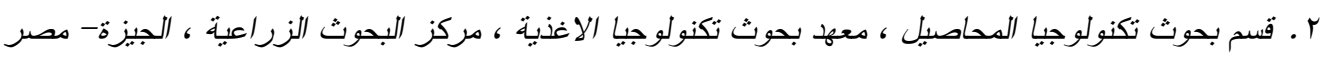

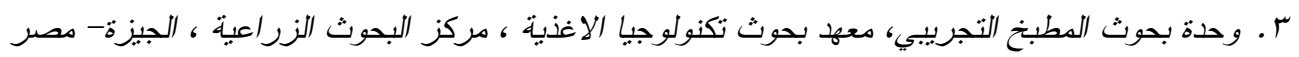

تمنل مخلفات الفو اكه والخضروات الناتجه خلال العمليات التصنيعية مشكله خطيرة للبيئة لــــا

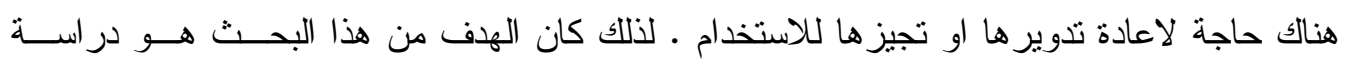

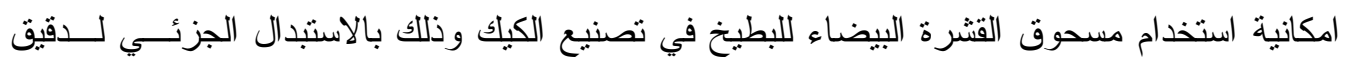

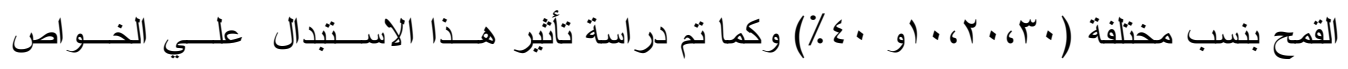

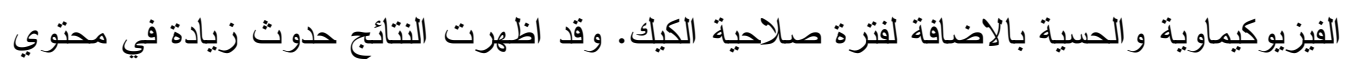

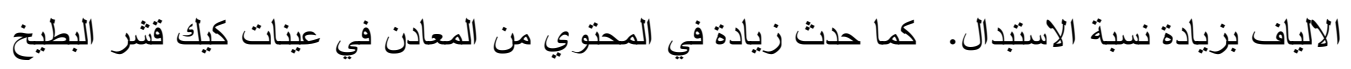
خاصة المحتوي من الكالسيوم و البوتاسيوم و الماغنيسيوم ـ وقد ادي اليضا الاستبدال بمسحوق فيدادئ القشرة

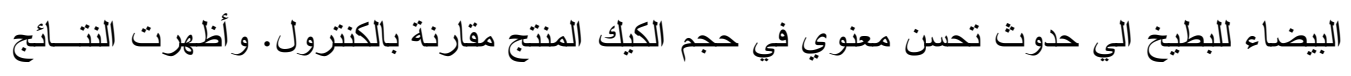

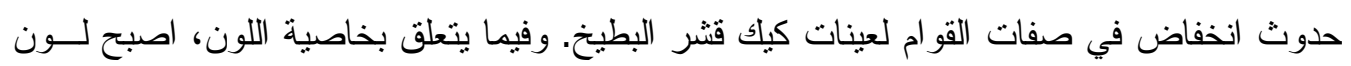

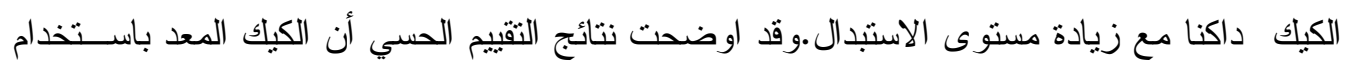

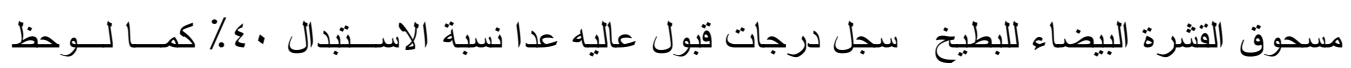

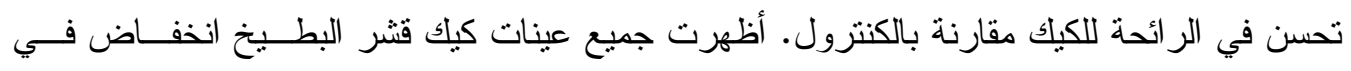

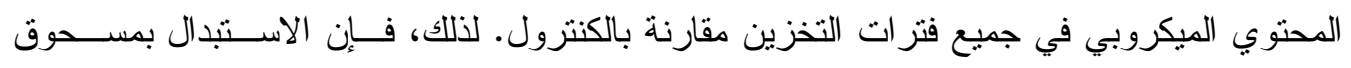

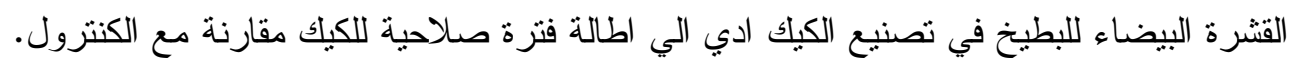

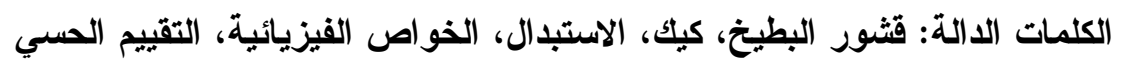

